\title{
THE DEVELOPMENT PROCESS AT KASSERINE REGION: SOME REFLECTIONS FOR A SOCIO-ECONOMIC STUDY
}

\author{
Nadia OUNALLI* \\ Lamia ARFA* \\ Anissa GARA**
}

\begin{abstract}
Despite its natural and archaeological potential and its position on the border with Algeria, the Kasserine governorate remains economically and socially disadvantaged, despite some progress made since independence. Since 2012, this governorate has been ranked last in socio-economic development. Indeed, this area recorded a regional development index of 0.16 against 0.50 for Médenine, 0.69 for Ariana and 0.76 for Tunis. Then, in 2018, this index remained the last ranking at the national level with a value of 0.41 against 0.530 for Médenine, 0.620 for Ariana and 0.630 for Tunis (ITCEQ, 2018). This paper consists of an analysis of the development situation in the Governorate of Kasserine, after the revolution of January 14, 2011.
\end{abstract}

Keywords: development policies; development process; indicators; Kasserine; socioeconomic study

DOI: 53373 / REDS.2021.53.4.052

\section{Introduction}

Over the past 60 years, Tunisia has undergone profound economic, demographic and socio-cultural changes. These changes were mainly induced by public development policies implemented by the State since independence. These policies have been truly successful, resulting in increased production and an improved standard of living, as proved by the main development indicators.

The State has had the monopoly of expertise and the main donor; it has set up master planning schemes reflecting the major options for centralized development.

The main instruments for the application of planning outlines deal with development projects through sectors and via chains also more rarely at regions. and para public enterprises (such as the Offices). The space is mainly designed as a production basin. The emphasis is on the necessary investments, techniques and accompanying measures.

In the difficult areas of the west-central, ambitions have been more limited and policies have been implemented, mainly to address problems related to the access

\footnotetext{
* University of Carthage, Rural Economics Laboratory, Institute National de Recherche Agronomique de Tunis, Tunisie, nediaounalli@gmail.com.

** University of Carthage, National Agronomic Institute of Tunisia, Tunisia.

*** University of Carthage, National Agronomic Institute of Tunisia, Tunisia.
} 
and the use of natural resources (water, soil and vegetation) (Belhadi, 2005). But herein as well, public policies have regarded infrastructure and agriculture. They have mainly promoted agricultural hydro investments, water and soil management and conservation, and rangeland and forest management (Ounalli, 2014).

The benefits of development have been unevenly distributed over the different regions of the country and economic growth has been more in favor of some areas much more than others (Bechir R, 2014).

The revolution of January 14, 2011 has called into question regional development policies, particularly in the interior regions of the country, which have suffered from real marginalization compared to the coastal regions (Ounalli and Bechir, 2020). Indeed, despite the progress recorded by the national economy, it must be noted that the gap between regions has not ceased to raise, several indicators attest it, leading to a real territorial disparity in terms of economic and social development (Belhadi, 2016).

This paper presents the development situation at the governorate of Kasserine regarded as an arduous region classified among the poorest regions of the interior of Tunisia. This work is based on a literature review and on data and studies made on this region.

It is structured in three parts. First, it is a question of spreading the structural data and resources deployed in the governorate of Kasserine. Then, the sectors of activities and their characteristics are defined. Finally, some development indicators and recommendations are presented.

\section{Resources and economic structures of the governorate of Kasserine}

\subsection{Resources and land structures}

The governorate of Kasserine is located in central-western Tunisia and covers an area of $8260 \mathrm{~km} 2$, that is to say $5.2 \%$ of Tunisia. It is made up of 13 delegations (see figure 1). It runs along the Algerian border to the east for a length of $220 \mathrm{~km}$. Hence the importance of trade and the informal economy with Algeria. 


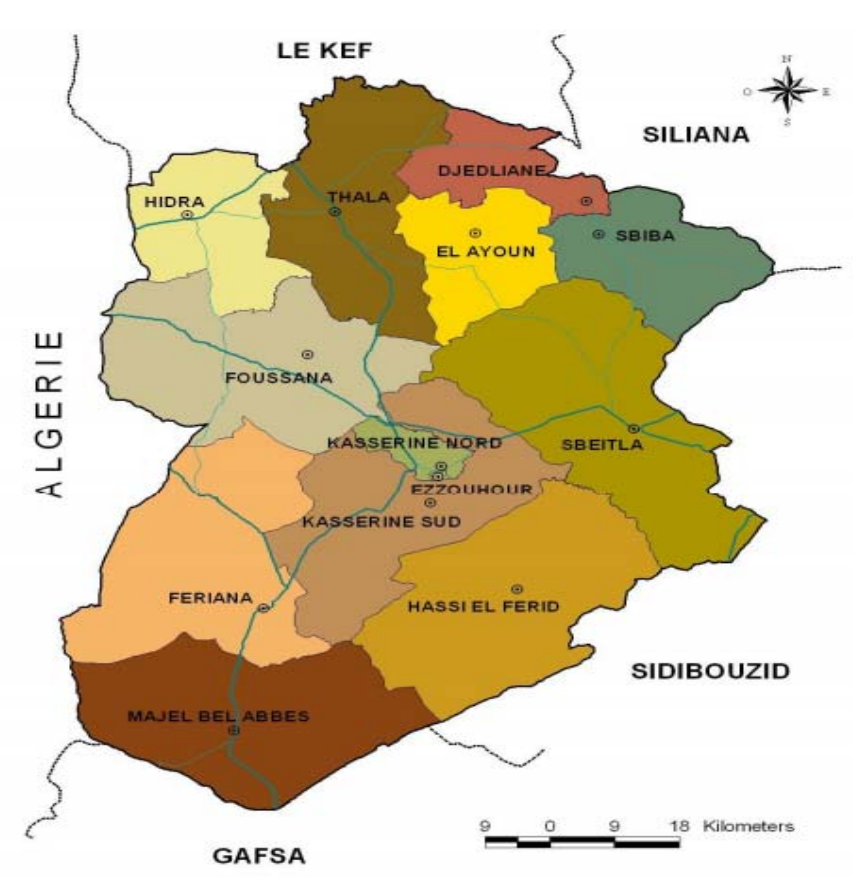

Figure 1. Map of the governorate of Kasserine

Geographically, the governorate of Kasserine belongs to the High Steppes region of Central Tunisia. It is largely located in the arid bioclimatic stage with a cool winter; the rest is located in the semi-arid bioclimatic cool stage. Its reliefs are marked by the existence of mountains, highlands and extended plains. More than half of the region's territory is at an altitude of between 800 and 1,544 meters and the highest point is that of Jebel Chaambi $(1,544 \mathrm{~m})$. This makes agricultural activities and travel difficult.

On the historical level, the governorate of Kasserine includes a very large number of archaeological sites and monuments (triumphal arches, theaters, forums, capitols, citadels, churches, temples, baths, fountains ...) that testify to the strategic, political and economic role it has played during its history (GIZ, 2015). This illustrates a strong potential for the development of tourism and leisure activities.

The number of farms increased over the period 1995-2005 (see Table 1) due to the division of land by inheritance. Small farms of less than 10 hectares account for $63.4 \%$ of the total number of farms. 
European Journal of Social Law

\begin{tabular}{|c|c|c|c|c|}
\hline \multirow{2}{*}{ Table1. Evolution of the structure of agricultural farms in the governorate of Kasserine } \\
\hline \multirow{2}{*}{ Area (ha) } & \multicolumn{2}{|c|}{$\mathbf{1 9 9 5}$} & \multicolumn{2}{c|}{$\mathbf{2 0 0 5}$} \\
\cline { 2 - 5 } & $\begin{array}{c}\text { Number of } \\
\text { farms }\end{array}$ & Part (\%) & $\begin{array}{c}\text { Number of } \\
\text { farms }\end{array}$ & Part (\%) \\
\hline$<\mathbf{5}$ & 10,700 & 39.9 & 12,297 & 36.9 \\
\hline $\mathbf{5 - 1 0}$ & 6,500 & 23.7 & 8,835 & 26.5 \\
\hline $\mathbf{1 0 - 2 0}$ & 5,500 & 19.8 & 6,574 & 19.7 \\
\hline $\mathbf{2 0 - 5 0}$ & 4,000 & 14.4 & 4,530 & 13.6 \\
\hline $\mathbf{5 0 - 1 0 0}$ & 700 & 2.5 & 924 & 2.8 \\
\hline$>\mathbf{1 0 0}$ & 200 & 0.7 & 190 & 0.6 \\
\hline Total & 27,800 & 100 & 33350 & 100 \\
\hline
\end{tabular}

\subsection{The population}

The population of the governorate of Kasserine reached 460 thousand people in 2020 with an average annual growth rate decreasing: from $0.65 \%$ in 2014 to $0.47 \%$ in 2020 (see Table 2). In addition, since the 1990s, the governorate has continued to record emigration flows to the North and Sahel regions. Thus, the average population density is 53 inhabitants per $\mathrm{Km} 2$ against a national average of 67 inhabitants per $\mathrm{Km}^{2}$.

Table 2. Population growth in the governorate of Kasserine

\begin{tabular}{|c|c|c|c|}
\hline Year & $\mathbf{1 9 9 4}$ & $\mathbf{2 0 0 4}$ & $\mathbf{2 0 1 4 \mathbf { 2 0 2 0 }}$ \\
\hline Population of Kasserine (inhabitants) & 386,908 & 412,278 & 439,243 46,0000 \\
\hline $\begin{array}{c}\text { Average annual growth rate at } \\
\text { Kasserine }\end{array}$ & $2.6 \%$ & $0.64 \%$ & $0.65 \% 0.47$ \\
\hline \begin{tabular}{c} 
Average annual growth rate at Tunisia \\
\hline
\end{tabular} & $2.3 \%$ & $1.21 \%$ & $1.03 \% \ldots \ldots$ \\
\hline
\end{tabular}

\subsection{Private and public investment}

Public investment was mainly intended at the conventional government's domain of intervention, namely infrastructure works and public facilities. Efforts have been limited in most cases to social interventions, development sites, roads, schools, health centers, agricultural tracks, electrification, access to drinking water and the fight against rudimentary housing.

The analysis of the evolution of public and private investment shows that Kasserine region has not benefited from a consistent exertion of investment that would lead to a significant change in the economic and social situation of the region, despite some accomplishments (PDAI, 2018). Indeed, in spite of the State's investment effort, the region has not benefited -in recent decades- from constructing investments able to convert meaningly and positively into economic outcomes. 


\section{Sectors of activities}

\subsection{Manufacturing industry and tourism}

Activities related to manufacturing industries started with the installation of the cellulosic complex in 1963 at Kasserine city center. Then several projects were mounted such as the Tunisian-Algerian Society of White Cement, the Tunisian Society of Lime, the Marble Industry of the West and subsequently the Ceramics of the West was privatized. However, Kasserine region has had a turbulent history, with a succession of periods of recovery and others of disruptions correlated to political choices in industrialization and regional development.

As a result, Kasserine region has not been able to build a sound industrial basis that allows the expansion and diversification of the industrial sector and the creation of wealth and stable jobs for the benefit of local populations.

Kasserine region has substantial and diverse touristic potential that is not fully utilized and underscored. It is the largest reservoir of Roman ruins in the country. It represents the largest reserve of Roman ruins in the country. Indeed, it is important to note the 24 rural sites (Henchir Tamouda, Henchir el Begar, Henchir el Khima,...) that are neither guarded nor reported on the road network of the region. Besides, the governorate is also known by its urban sites namely: Sbeïtla, Haidra, Feriana, Thala, Sbiba and Kasserine. In addition to these tourist assets of the region, there is the the national park of the mount: «Jebel Chaambi» created in 1980 and covers an area of about 7000 ha.

\subsection{Agriculture}

Kasserine governorate is one of the most countryside regions of Tunisia with a rural population rate of $60 \%$. Agriculture is the main economic activity in the region, counting for $29.2 \%$ of the employed labor force, compared to $17.5 \%$ nationally. In fact, according to the 'Farms' Structures Survey' (of the years: 2004/2005) there are 33,350 farmers and 2,035 permanent employees working at agricultural activities. Definitely, agricultural activity is a refuge for a large part of the population, due to the very limited employment opportunities in other sectors.

Since the 1990s, changes in agrarian systems and agricultural practices have been recorded. These changes have resulted in the reduction of extensive livestock farming, the specialization of agriculture and the extension of arboriculture, especially olive crops, leading to some abandonment of cereal farming. There is also the clearing of rangelands, the conversion of cereal and pastoral areas into arboricultural areas and the use of extra-agricultural activities.

Commitment to the inclusion into market economies, these changes have been convoyed by a decrease in the consumption of local agricultural products, an increase 
in monetary charges at the household level, and the development of monetary needs. They have also increased social and regional disparities (Béchir, 2020).

Agricultural production does not fully meet population's expectations. The modernization of agriculture was based on the model of the green revolution characterized by agricultural intensification and innovation. There has been an intensification of the production system through the use of improved seeds, chemical fertilizers, treatment products and mechanization (Ounalli, 2014).

The apple of Sbiba, like the pomegranate of Gabes, was the first species to obtain, in 2009, the Indication of Origin (IO) whose grant is linked to the compliance to a logbook of specification. Regrettably, only 150 farmers have adhered to the IP (PDAI, 2018).

The prickly pear is mainly planted in Thala and in Zelfen (25000 ha) where the plantations are sometimes irrigated or receive additional irrigation when needed. Some researches about the prickly pear in the region led to catalogue it as a fruit of good quality. The prickly pear is a great regional potential whose development has led to the creation of two GDA bringing together 870 farmers and the installation of an industrial processing unit. However, prickly pear cultivation remains hampered by the poor management of plantations with quite low yields $(5 \mathrm{~T} /$ ha/year against 20 $\mathrm{T} / \mathrm{ha} / \mathrm{year}$ in Italy), by the loss of about $40 \%$ of the production and by the very low valorization of the production (GIZ, 2015).

\section{Development indicators}

Different types of indicators have been calculated and make it possible to estimate the state of human and economic development in Kasserine governorate and to compare it to the national situation.

\subsection{The health index and the social aspect index}

Kasserine governorate has the lowest health index after Sidi Bouzid governorate compared to other parts of the country (Souissi M, 2018). This is due to the problematic access to healthcare services. In fact, medical density is very low ( 0.4 doctors per 1000 inhabitants).

The index relating to the social aspect is decisive and reflects strong disparities. Indeed, the governorates most affected by illiteracy and poverty are still the same, reporting to the governorates of the interior like Jendouba, Kasserine, Kairouan, and Siliana. Although the number of families in need has increased, the level of development has stagnated (ITCEQ, 2018).

These two indicators reflect the low level of attractiveness and the inability to captivate local labor supply reflecting the vulnerability of the labor market. Indeed, 14 out of 24 governorates have development levels below the indicator average. The 
governorate of Kasserine lags behind the national average in terms of number of enterprises, placement rates and employment opportunities (Souissi, 2018).

Kasserine governorate recorded a high unemployment rate in 2018 estimated at $24.1 \%$ compared to $26.2 \%$ in 2012 . At the national level, this rate was estimated at $15.4 \%$ in 2018 and $17.6 \%$ in 2012. In Tunisia, the unemployment affects particularly young graduated of higher education at the rate of $29.2 \%$; it is a serious challenge for the country and especially for the regions of the interior.

\subsection{The index of extreme poverty}

According to the INS (2005's data), the extreme poverty index places Kasserine governorate at the top ranking of all governorates along with Kairouan governorate with a poverty rate of $10.2 \%$ and $10.3 \%$ respectively while only $4.6 \%$ for Monastir, $6.3 \%$ for Sousse, $6.9 \%$ for Tunis and $7.6 \%$ for all of Tunisia.

The analysis of extreme poverty by governorate reveals very strong regional disparities (Figure 2). Indeed, the problem of poverty is almost non-existent in coastal cities, but it is very important in the central-western regions, particularly Kef $(34.2 \%)$ and Kasserine (32.8\%).

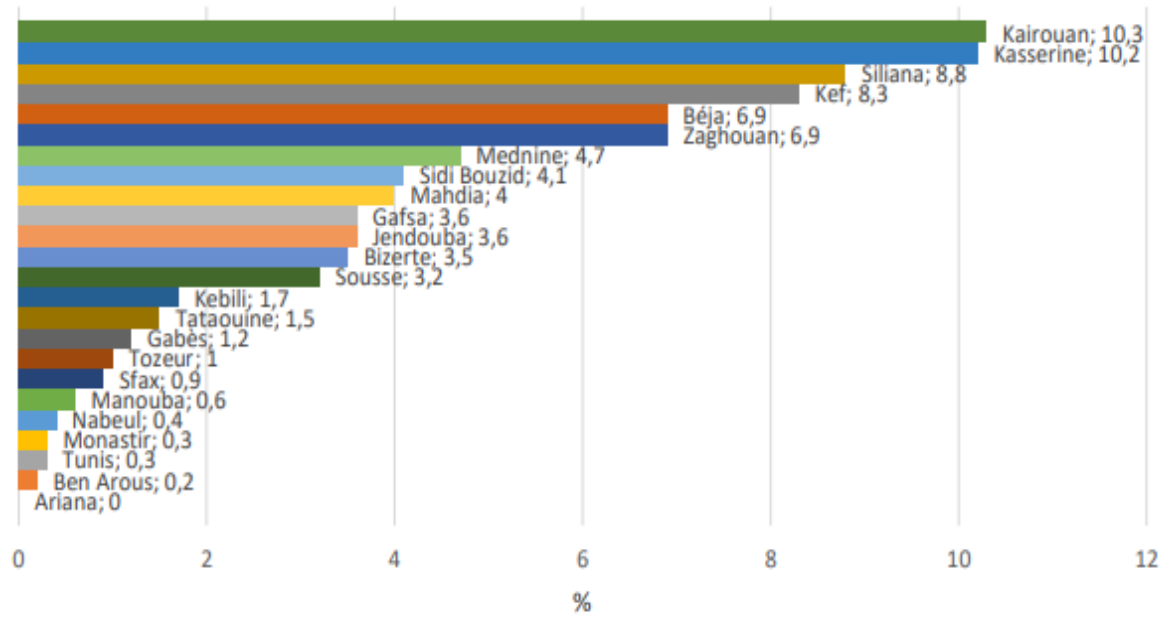

Figure 2. Extreme poverty in regions (ITCEQ, 2015)

\subsection{Regional Development Index (RDI)}

It is the synthetic indicator of regional development. Kasserine governorate recorded the lowest regional development indicator in Tunisia in 2018: at 0.41 (Figure 3) (ITCEQ, 2018). This governorate remains economically and socially disadvantaged, despite some progress since independency. 


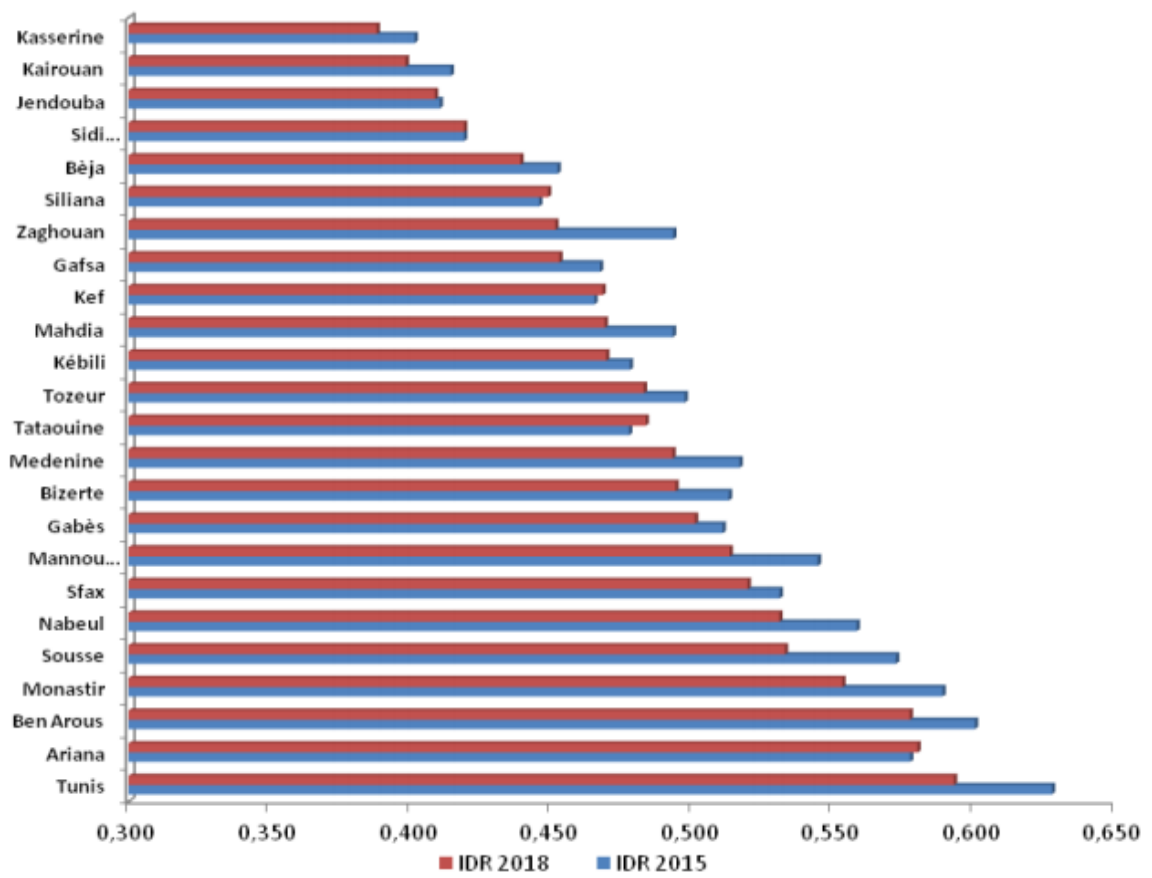

Figure3. Regional Development Indicator (Source: ITCEQ, 2018)

\section{CONCLUSION}

In Tunisia and before the 2011's revolution, wealth allocation and development efforts have historically converged towards coastal regions and cities (Belhadi, 2014). The center part of the country has been marginalized except for some projects with a low development impact. Public development policies seem to have ignored poverty in these areas since the 1950s.

In Kasserine governorate, the delay happening on the development process has accentuated the regional disparity between governorates on the one hand and between rural and urban areas on the other. Investment and development efforts, albeit modest, have mostly benefited the urban environment. The most important indicators of this disparity are related to urbanization and migration flows. To reduce regional disparities a redefinition of the role of economic spaces is required. On the one hand, in the countryside, the transformation of structures and the reduction of gaps between the modern and traditional sectors must be accompanied by the training and mobilization of manhood. On the other hand, in the metropolitan, the 
state of concentration of the network must evolve towards decentralized, regionally integrated and labor-intensive forms of organization.

Moreover, throughout the last decade, economic difficulties have intensified and have led to an increase in production costs and problems in the disposal of agricultural products. The region also suffers from overexploitation of natural resources. Public policies have failed to create a sustainable development dynamic. These limitations have resulted in an unprecedented resumption of the rural exodus with or without transmission of land (Dimassi, 2009). Today and after the revolution, public policies try to reconcile social equity, sustainable resource management and economic competitiveness. They try to respond to people's aspirations for development. For both economic and political reasons, decentralization and the participation of the population are promoted to bring economic decisions closer to the beneficiaries. The need arises for an institutional relay that brings out the concept of territorial development that takes into account the interactions between local and political actors of the State.

Moreover, the governorate of Kasserine has enormous natural and human potential. Agricultural development priorities arise, such as the promotion of agricultural products through processing, packaging and the creation of labels for Zalfane prickly pears. Agriculture also offers other specific crops (cherries, table grapes, apples, organic crops). The food industry sector can develop the drying of tomatoes, the processing of milk, the storage and packaging of fruits and vegetables, and finally the extraction of food and essential oils.

Priorities to cultural development for the archaeological heritage is Necessary and a Must. Archaeological sites should be restored, their environments improved, and access and visitation routes developed. Opportunities for private investment should be encouraged. The industry sector will be interested in the extraction, processing and reconstitution of marble, the exploitation of quarries (limestone, stone, gypsum, clay...), the glass industries, etc.

\section{BIBLIOGRAPHICAL REFERENCES:}

- Abaab A., 1999. Agricultural modernisation and its effects on agricultural production systems: the case of the Sidi Bouzid region in Central Tunisia. PhD Thesis, University of Gant, Belgium, $330 \mathrm{p}$.

- Bechir R, 2014. Sustainable development and regional disparity in Tunisia. A study on the Millennium Development Goals in Tunisia. Paf; ISBN: 978-3-8381-4917-2.

- Bechir R, Ounalli N. Mhemed Jaoued et Mongi Sghaier, 2020. Regional disparities and local development in southern Tunisia. New Medit - A Mediterranean Journal of Economics, Agriculture and Environment. No. NEMED-D-20-00010R1.

- Bechir R, 2019. What solutions for sustainable local development in Tunisia: A study of the three municipalities: Médenine, Béni Khedache and Tataouine (South-East Tunisia). Editions Universitaires Européennes EUE. ISBN10 6139513375.

- Belhadi A, 2005. Regional Economic Dynamics. Recent Features and Trends. StructuralResidual Analysis. Cybergeo, No. 310, 09/05/2005. 
- Belhadi A, 2014. Unequal regional development in Tunisia: Spatial accumulation and littorisation. In: Cahiers de la Méditerranée, $n^{\circ} 49,1,1994$. Tunisia, a dynamic of change. pp. 133-156.

- Belhadi A, 2016. Territory, territorial development, geo-governance. Arid Regions Review. ISSN: 0330-7956).

- Dimassi H., 2009, « The macro-social context: poverty and precariousness in difficult areas in a context of globalization. Societies in Transition and Local Development in Zones difficult ". Proceedings of the International Colloquium, Jerba; 22-24 April 2009, IRA Médenine,Jerba, Tunsie, $4 \mathrm{p}$.

- Elloumi M, 2006. Rural development policies in Tunisia; Achievements and perspectives. International Seminar; sustainable rural development policies in the Mediterranean within the framework of the European Union's Neighbourhood Policy (2007/2013), 8/9 February 2006- Cairo, Egypt.

- GIZ, 2015. Regional Sustainable Development Plan (PREDD) of Kasserine Governorate Synthetic document.

- Tunisian Institute of Competitiveness and Quantitative Studies (ITCEQ), 2018. Regional Development Indicators: Methodology and Results. ITCEQ Notes and Analyses.

- Ounalli N, 2014. Impact of public development policies on the functioning and sustainability of activity systems: The case of the Oued Oum Zessar watershed, South-East Tunisia, Médenine». PhD thesis in Geography and Spatial Planning: PhD thesis defended on 22 October 2014, at University of Montpelier 3.

- Ounalli N, Bechir R, 2020. Territorial inequality in the Governorate of Kasserine; a highlight through the analysis of regional development indicators, Central-West of Tunisia. Volume 72. June 2020. Journal of New Sciences (JNS: ISSN 2286-5314).

- Ministère du Transport et de l'équipement, 2011. Atlas of the Governorate of Kasserine.

- PDAI, 2018. Feasibility Study of the Integrated Agricultural Development Project. CRDA Kasserine.

- Sghaier M., Abaab A., Campagner P., 2006. Experimentation with new approaches to local development and participatory management of natural resources. In: Genin G., Guillaune H., Ouessar M., Ouled Belgancem A., Sghaier M., Tâamallah H. (ed.), Between desertification and development: The Tunisian Jeffara. Cérès editions, Tunis (Tunisia), pp.303-312.

- Souissi M, 2018. Local Power for Development: What Budget Allocation Rules? Center of Mediterranean and International Studies. 12p.

- Tonneau JP., 2008. Why the hell territorial development, and even more, why believe it?" , Working Papers Icare, Summary Notes series $-n^{\circ} 4$, Cirad, Montpellier, 17 p. Cirad, Department of Environment and Societies, 2008. Baillarguet International Campus. 34398 Montpellier Cedex 5, France. 